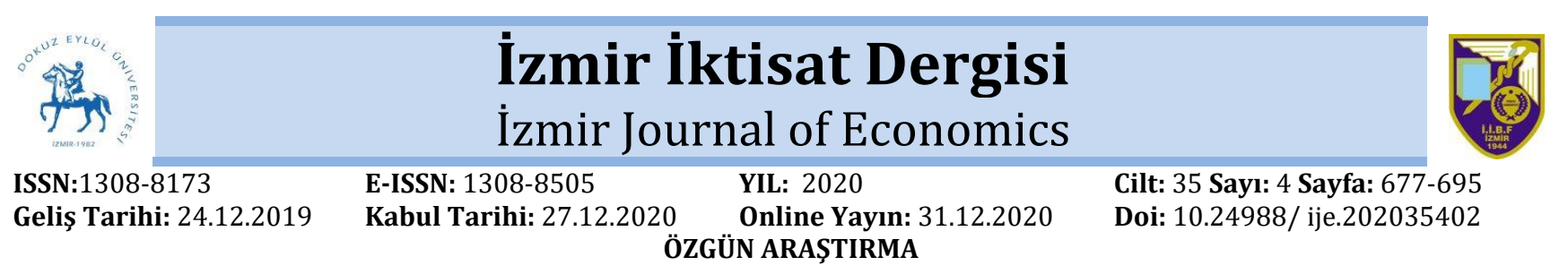

\title{
Teknoparklar Odağında Açık İnovasyon Etkisi: Dokuz Eylül Teknoloji Geliştirme Bölgesi İncelemesi
}

\author{
Muratcan KARAGÖZ1 ${ }^{\text {, Yılmaz GÖKŞEN² }}{ }^{\text {, Mete EMİNAĞAOĞLU }}{ }^{3}$
}

\begin{abstract}
Özet
İnovasyon ve Ar-Ge, ülkelerin gelişmişlik düzeylerinin ve ekonomisinin değer kazanması açısından büyük önem taşımaktadır. Türkiye'de teknoloji geliştirme bölgelerinde Ar-Ge ekosisteminin gelişimi hızla artarak devam etmektedir. Çalışmamız genel olarak Ar-Ge ve inovasyonun dünyadaki ve Türkiye'deki durumuna gelişim süreçlerine, mevcut konumuna yer vermiştir. Çalışmanın uygulama kısmında Dokuz Eylül Teknoloji Geliştirme bölgesinde faaliyet göstermekte olan yazılım sektöründeki işletmeler içinde açık inovasyonun etkisine yönelik bir uygulama gerçekleştirilmiştir. Klasik istatistikyöntemlerinin yanı sıra veri madenciliği algoritmalarından Apriori algoritması ve birliktelik kuralları çerçevesinde analiz edilmiştir.
\end{abstract}

Anahtar Kelimeler: Bilgi yönetimi, açık inovasyon, Ar-Ge, Apriori algoritması, birliktelik kural analizi Jel Kodu: C83, C89, D83, 032

\section{The Impact of Open Innovation within Technology Parks: Dokuz Eylül Technology Development Zone Analysis}

\begin{abstract}
Innovation and $R \& D$ are crucial for the enhancement of countries' development levels and economies. The development of technology in $R \& D$ ecosystem continues to increase rapidly in Turkey. Our study focuses on the current issues in $R \& D$ and innovation processes in Turkey and around the world. A survey and research have been conducted for the analysis of the impact of open innovation in software business at Dokuz Eylül Technology Development zone. The results are analyzed and discussed where association rules by Apriori algorithm have been used as well as the classical statistical techniques.
\end{abstract}

Keywords: Information management, open innovation, R\&D, Apriori algorithm, association rule analysis Jel Codes: C83, C89, D83, 032

\section{GíRiş}

Ar-Ge terimi, İngilizce "Research and Development" olarak adlandırılan terimin Türkçe karşıllğı olup araştırma ve geliştirme faaliyetlerini ifade etmek için kullanılmaktadır. Ülkemizin tarihsel gelişiminde, gerek devlet politikaları gerekse yapısal reform, kanun ve teşvikler ile Ar-Ge faaliyetlerine verilen önem incelendiğinde, Ar-Ge faaliyetlerine yönelik birçok farklı çalışma karşımıza çıkmaktadır.

Türkiye'de Ar-Ge faaliyetlerinin planlı olarak başlaması, 1963 yılında Türkiye'nin bilim ve teknoloji politikalarının oluşturulmasına dayanmaktadır. 17.07.1963 yıl ve 278 sayılı kanun ile kurulmuş olan Türkiye Bilimsel ve Teknolojik Araştırma Kurumu (TÜBİTAK) ile başlayan süreç, bu konuda atılmış ilk somut adım olarak bilinmektedir. İşletmelerin

ATIF ÖNERİII (APA): EMINAĞAOĞLU, M., KARAGÖZ, M., GÖKȘEN, Y. (2020). Covid-19 Teknoparklar Odağında Açık İnovasyon Etkisi: Dokuz Eylül Teknoloji Geliştirme Bölgesi İncelemesi. İzmir İktisat Dergisi, 35(4), 677-695. Doi: 10.24988/ije.202035402

1 Proje Destek Birimi Sorumlusu, DETTO Dokuz Eylül Teknoloji Transfer Ofisi, Buca / İZMIR,

EMAIL: muratcan.karagoz@deu.edu.tr, ORCID: 0000-0002-2630-0138

2 Prof. Dr., Dokuz Eylül Üniversitesi, İktisadi ve İdari Bilimler Fakültesi, Buca / İZMİR,

EMAIL: yilmaz.goksen@deu.edu.tr ORCID: 0000-0002-2291-2946

3 Dr. Öğr. Üyesi, Dokuz Eylül Üniversitesi, Fen Fakültesi, Buca / İZMİR,

EMAIL: mete.eminagaoglu@deu.edu.tr ORCID: 0000-0003-2456-919X 
sürdürülebilir olabilmeleri için, yenilik faaliyetlerine katılımları ve Ar-Ge faaliyetlerinde yer almaları önem taşımaktadır.

İnovasyon kavramını ilk kez ortaya atan ekonomist ve siyaset bilimci Schumpeter inovasyonu "ekonomik kalkınmanın itici gücü" olarak tanımlamıştır. Schumpeter, 1911'de yayınlanmış ve 1934'te İngilizce çevrisi yapılmış olan kitabında inovasyonu yeni bir ürünün piyasaya sürülmesi, bilinen bir ürünün farklılaştırılması, yenilenmiş üretim yöntemlerinin uygulanması, yeni bir pazar yaratılması, tedarik için yeni kaynaklar elde edilmesi, yarı mamul ürünler ile ilgili yeni bir endüstriyel yapı yaratılması olarak tanımlamıştır (Schumpeter, 1934).

Teknopark kavramı, bilim ve sanayi alanında yaklaşık 65 yıldır bilinmektedir. Teknopark kavramı Terman'ın görüşüyle ortaya atılmış ve bu kavramın șekillenmesi, 1950' de Stanford Üniversitesi'nin de katkıları ile tarımsal vadinin yarı iletkenler ve bilgisayar endüstrisinin doğmuş olduğu silikon vadisine dönüşmesi sonucunda olmuștur. 1951 senesinde ilk defa modern bir bilim parkının kuruluşu gerçekleştirilmiştir. $\mathrm{Bu}$ yapı daha sonra Stanford Araştırma parkı ismini almıştır. Silikon vadisi ilerleyen yıllarda ABD'de hızl büyüyen kentsel alanlardan biri haline gelmiştir. (Annerstedt, 2006:284) Günümüz dünyasında "Silikon Vadisi" olarak bilinmekte olan bu bilim parkı (Teknopark), teknoloji dünyasında en çok rağbet gören ve tanınan en başarılı inovasyon ve teknoloji merkezidir (Basile, 2011:5).

Türkiye'de teknoloji geliştirme bölgelerinin kurulması ve oluşturması çabaları 1980'li yılların başında başlamıştır. Bu çalışmalar sonucunda ilk adım olarak Küçük ve Orta Ölçekli İşletmeleri Geliștirme ve Destekleme İdaresi Başkanlığı (KOSGEB) aracılığı ile teknokentlerin ilk adımı olarak teknoloji geliştirme merkezleri (TEKMER) kurulmaya başlamıştır.

$\mathrm{Bu}$ çalışmanın amacı, teknoparklar odağında açık inovasyonun etkisinin araştırılmasıdır. $\mathrm{Bu}$ kapsamda dünyada ve Türkiye'de teknoloji geliştirme bölgelerinde en çok faaliyet gösteren yazılım sektöründeki ișletmeler ele alınmıștır. Uygulama, İzmir'de bulunan DEPARK (Dokuz Eylül Teknoloji Geliştirme) bölgesindeki yazılım sektöründe yer alan işletmelerde açık inovasyonun etkisine yönelik olarak gerçekleştirilmiştir.

\section{AR-GE VE TEMEL KAVRAMLAR}

Ar-Ge alanına ilișkin önemli kaynaklardan birisi 1963 yılında İtalya'nın Frascati Kasabası'nda Ekonomik İşbirliği ve Kalkınma Örgütü tarafından hazırlanan kılavuzdur. Frascati kılavuzuna göre Ar-Ge, "İnsanlık, kültür ve toplum bilgisi dâhil olmak üzere bilgi birikimini artırmak ve var olan bilginin yeni uygulamalarda kullanılması için yürütülen yaratıcı ve sistematik çalışmaları" ifade etmektedir (OECD, Frascati Kılavuzu, 2002:50). Ar-Ge; var olan süreci yenileme, yenilik, yeni icatlar yaratma, ürün geliștirme kapasitesine sahip olan teknoloji ve yenilikle ilgili etkinliklerden oluşmaktadır. İşletmeler tarafından yapılan yatırım ve harcamalar sonucunda katma değeri yüksek olan ürünlerin ortaya çıkması, bu kuruluşlar için en önemli sermayeyi oluşturmaktadır (Yaylalı vd., 2010:14). Bir başka tanıma göre Ar-Ge, yeni bir ürünün ortaya konulması yanı sıra bu ürünün geliştirme sürecinde ortaya çlkan bilgi birikimini ve bu birikimin ileriye dönük olarak kullanılmasını da kapsamaktadır (Satı, 2013:17).

Ar-Ge kavramının kapsamına bakıldığında; yönetim ve organizasyon, finansman, üretim ve üretim tekniği, personel yönetimi gibi genel işletme özelliklerinin verimliliğinin artırılması amaçları gözlemlenmektedir. İlgili göstergeler göz önünde bulundurulduğunda araștırma; daha önce bulunmamış bir teknoloji, ürün ya da bilgiyi geliştirmek ve bunu uygulamaya koymak için yapılan faaliyetler bütününü kapsamaktadır (Ünal ve Seçilmiş, 2013:7). ArGe'nin temel amaçlarından birisi sürekli dönüşmekte olan ekosistemde faaliyet gösteren firmaların dönüşümlere uyumlarını gerçekleștirmek, firmaların dönüşümler sonucunda büyümelerini ve sürekliliğini sağlayarak değer yaratmalarını 
amaçlamaktadırlar. Firmalar, varlıklarını sürdürebilmeleri ve amaçlarını gerçekleştirmeleri için sürekli bir değişim içerisinde bulunmalıdır. Geçirdikleri değişimlerden dolayı, kuruluşlar sistemli olarak Ar-Ge faaliyetlerinde bulunarak kendi sürdürülebilirliklerini sağlamalıdır (Zerenler vd., 2007:8).

\section{3. İNOVASYON VE TEKNOLOJI GELIŞTTIRME BÖLGELERI}

İnovasyon, girişimcilerin yeni kaynaklar yaratmalarını veya katma değer elde etmeleri için mevcut kaynaklarını geliştirmelerini sağlayan bir araç olarak görülmektedir (Drucker, 1985). İnovasyon, yeni ürünlerin pazar paylarının artırılmasına hizmet etmekte ve ticari kazanç elde etmek amacı ile yürütülen tüm planlama, yönetim, üretim ve ticari faaliyetleri kapsamaktadır (Freeman, 1982).

İnovasyon, icat ya da buluş ile genelde karıştırılabilen kavramlardır. İcat, yeni bir üretim yöntemi, ürün ya da fikrin ilk defa geliştirilmesi aşamasını oluşturmaktadır. Bir icadın inovasyon olabilmesi için ise, ticarileșmesi ve yıkıcı bir fark yaratması gerekmektedir. Bu kavramları birbirinden ayırt etmek belirtilen nedenlerden olayı zorlaşmaktadır (Fagerberg, 2003:4). İncelenen inovasyon tanımların birçoğunda yeni ya da yenilik kelimesi yer almaktadır.

\section{1. İnovasyon Türleri}

\section{İnovasyon}

konusundaki

literatür

incelendiğinde çeşitli kaynaklarda farklı biçimde sınıflandırıldığı görülmektedir. Schumpeter inovasyonu beş farklı türe ayırarak incelemiştir: yeni üretim yöntemleri, yeni pazarlara giriş, yeni ürünler, yeni tedarik kaynakları ve yeni tipte iş planlarının yapılması. Ürün ya da süreçle ilișkili yenilikler yanı sıra pazarlama ve organizasyona yönelik yenilikler de bu türler içinde yer almaktadır (Günday vd., 2011). Büyük bir yoğunluk içinde yaşanan Ar-Ge aşamaları sonucunda ortaya çıkan yeni bir pazar ya da daha önce piyasada hiç olmayan tamamen yeni bir ürünün üretilmesini sağlayan inovasyona ise radikal inovasyon denmektedir (Tekin vd., 2003:139).

İşletmenin bilgi birikimi ve yeteneklerinde iyileşmeye ve gelișmeye neden olan yenilikler aşamalar halinde gerçekleșmekte ise, buna kademeli artımsal inovasyon denmektedir. Örneğin cep telefonu teknolojisinin günümüze kadar geldiği süreçte birçok yeni özellik kazanarak gelişmeye devam etmesi artımsal inovasyon örneğini oluşturmaktadır (Uzkurt, 2008:63). Öte yandan, insanllk tarihinde ilk defa kullanılmaya başlanan cep telefonu teknolojisi ve modeli ise radikal inovasyona örnektir.

İnovasyon türünün birçok boyutta tanımlanabileceği varsayılmaktadır. Ancak, inovasyon türleri ürün inovasyonu, süreç inovasyonu, pozisyon inovasyon, paradigma inovasyonu olarak dört türe indirgenebilmektedir (Bessant ve Tidd, 2007). OSLO kılavuzuna göre inovasyon türleri ürün inovasyonu, süreç inovasyonu, örgütsel inovasyon, pazarlama inovasyonundan oluşmaktadır (OECD, OSLO Kılavuzu, 2005:51).

\section{2. İnovasyon Yönetim Sistemi}

İnovasyonu gerçekleştirmek isteyen işletme kendi sistemi içinde bir yönetim yapısı oluşturmalıdır çünkü bu yapı, yeniliğin gerçekleşmesi için büyük bir önem taşımaktadır. Yeniliğin en önemli faktörü yönetimidir. Yönetimsel süreçler olmadan yeniliğin gerçekleşme olanağı yoktur (Çifçi vd., 2014).

Yenilik yönetimi, fırsatların ve olanakların değerlendirilip stratejilerin oluşturulmasını gerektiren bazı önemli süreçleri kapsamaktadır. Yenilik yönetim sistemi sürecinde işletme içerisinde bir yenilik kültürünün oluşması önem taşımaktadır. İșbirliği ve etkileşim olan ișletmelerde yönetim süreçleri daha hızlı ve sorunsuz gerçekleşebilmektedir (Güler ve Kanber, 2011:73). İşletmeler, yenilik geliştirebilmek için bazı özel durumları içeren bir inovasyon yönetim sistemi kullanmalıdır (Tuominen vd., 1999:141). İşletmelerin, yeniliğe dâhil olmaları 
için bu sürecin doğru yönetilmesi gerekmektedir. İnovasyon yönetim sistemleri bu açıdan önem taşımaktadır.

Yeniliği yönetebilme kapasitesi, süreçlerin yaratılmasına katkı sağlamaktır. Bazı liderler, güçlü bir muhalefetin karşısında farklılaşmaya zorlanır. Memnun olunan yenilikler kısa sürede kabul görmektedir. Motivasyonları yüksek olan yöneticiler bu sayede bașkalarına da motivasyon kaynağı olmaktadır (Adair, 2015:7).

\subsection{Farklılıklarıyla Açı ve Kapalı İnovasyon Kavramları}

İşletmeler başarı odaklı çalışmak için rekabet stratejilerini etkin olarak kullanmalıdır. $\mathrm{Bu}$ bağlamda, yenilik süreçlerini her zaman izlemeleri gerekir. Yenilikle ilgili farklı yollar aranması ve işletmenin maliyetlerini düșürerek kârlarını artırmasını istemeleri sonucunda inovasyon kavramı ortaya çıkmıştır. İnovasyonun tarihine bakıldığında 1934 yılına kadar geri gitmektedir fakat açık inovasyon kavramı 1960'lı yıllarda ortaya çıkmıştır. Fikrin yaygınlaşması, Chesbrough tarafından ortaya atılan kavramlar sonrası gerçekleșmiștir (Chesbrough, 2003:78).

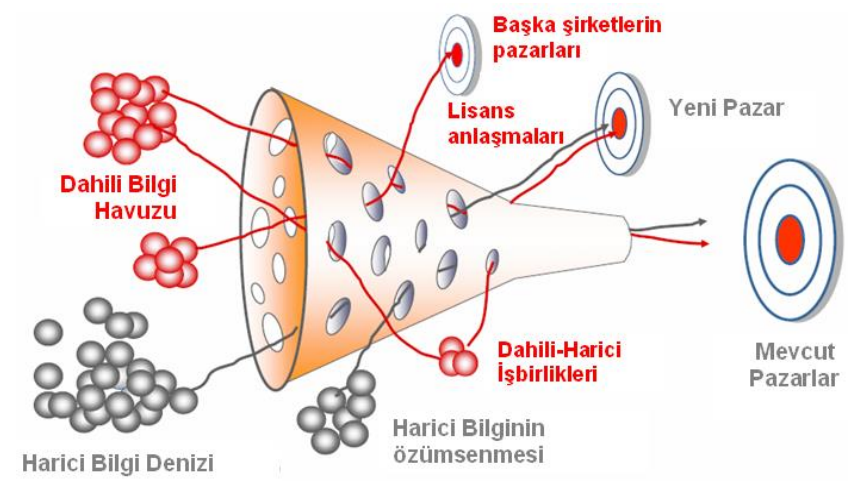

Şekil 1: Açık İnovasyon Modeli (Chesbrough ve Eichenholz, 2013)

Açık inovasyon aşamalarından önceki inovasyon dönemi kapalı inovasyon olarak adlandırılmıştır. İşletmelerin klasik biçimde ağırlıklı olarak içlerindeki bilgi birikimleri ile geliştirdikleri yeni uygulama ve hizmetler kapalı inovasyon olarak adlandırılmaktadır. Açık inovasyon aşamaları ise, genellikle dıșarıya açılım içeren inovasyon faaliyetlerin başlangıcl olarak tanımlanmaktadır (Chesbrough vd., 2006:90). Açlk inovasyon kavramı, bir organizasyonun yenilik süreçlerinde yer almakta olan kullandığı tüm aşamaların (iş modelleri, ürünler, hizmetler, süreçler vb.) bilgi birikimi ve kaynaklarının yetmediği durumlarda yeniliğin teşvik edilmesi amacı ile dışarıda yer alan işletmeler ve kişiler ile işbirliği yapılarak hızlandırılması olarak açılklanmaktadır (Oxford Review, 2019).

Tablo 1: Açık İnovasyon ile Kapalı İnovasyon Arasindaki Farklar (Chesbrough vd., 2006)

\begin{tabular}{|l|l|}
\hline \multicolumn{1}{|c|}{ Kapalı İnovasyon } & \multicolumn{1}{|c|}{ Açık İnovasyon } \\
\hline $\begin{array}{l}\text { Sektörümüzdeki dâhi } \\
\text { insanlar bizim için } \\
\text { çalışır. }\end{array}$ & $\begin{array}{l}\text { Bütün dâhi insanların } \\
\text { bizim için çalışmalarına } \\
\text { gerek yok. İhtiyacımız } \\
\text { olan şey içerde ya da } \\
\text { dışarıdaki akıllı } \\
\text { insanlarla } \\
\text { çalışabilmektir. }\end{array}$ \\
\hline $\begin{array}{l}\text { Ar-Ge'den yararlanmak } \\
\text { için, icat etmeli, } \\
\text { araştırmalı ve } \\
\text { geliştirmeli, bundan } \\
\text { faydalanmalıyı. }\end{array}$ & $\begin{array}{l}\text { taşıyan değerler } \\
\text { yaratabilir, dâhili Ar-Ge } \\
\text { ortaya çıkan değerin } \\
\text { tamamlayıcısı olmalıdır. }\end{array}$ \\
\hline $\begin{array}{l}\text { Eğer biz icat ettiysek, } \\
\text { ilk başlangıçta biz } \\
\text { piyasaya giriş } \\
\text { yapmalıyız. }\end{array}$ & $\begin{array}{l}\text { Kâr etmek için } \\
\text { araștırmaya ve } \\
\text { geliştirmeye ilk olarak } \\
\text { bizim başlamamıza } \\
\text { gerek yok. }\end{array}$ \\
\hline $\begin{array}{l}\text { Piyasaya yeniliği } \\
\text { başlangıçta çıkartan, } \\
\text { pazarda ilk kazanandır. }\end{array}$ & $\begin{array}{l}\text { Iyi bir iş modeli inşa } \\
\text { etmek, pazara başta } \\
\text { çlkmaktan daha iyi } \\
\text { olabilir. }\end{array}$ \\
\hline $\begin{array}{l}\text { Çalışma alanımızda en } \\
\text { iyi fikirlerin çoğunu } \\
\text { ortaya koyabilirsek, } \\
\text { fayda sağlayan biz } \\
\text { oluruz. }\end{array}$ & $\begin{array}{l}\text { Eğer iç ve dış kaynaklı } \\
\text { fikirleri en iyi kullanan } \\
\text { biz olursak, fayda } \\
\text { sağlayan da biz oluruz. }\end{array}$ \\
\hline $\begin{array}{l}\text { Kendi yeniliğimizi } \\
\text { olabildiğince } \\
\text { gizlemeliyiz ki } \\
\text { rakiplerimiz bizim } \\
\text { fikirlerimizden } \\
\text { faydalanamasın. }\end{array}$ & $\begin{array}{l}\text { Farklı paydaşların bizim } \\
\text { inovasyonlarımızı } \\
\text { kullanmalarından fayda } \\
\text { sağlayabilmeliyiz ve } \\
\text { başkalarının fikri } \\
\text { haklarını kendi iş } \\
\text { modelimiz için yararlı } \\
\text { olduğu zaman satın } \\
\text { alabilmeliyiz. }\end{array}$ \\
\hline
\end{tabular}


Açlk inovasyon Ar-Ge faaliyetlerinin iyileştirilmesinde kaldıraç görevi üstenerek Ar$\mathrm{Ge}$ faaliyetlerinin ivmelenmesi için bilgi girişinin ve akışının hızlandırılmasını amaçlayan sistemlerden oluşmaktadır (Kankanhalli ve Jonathan, 2013:76). Şekil 1'de açık inovasyonu tanımlayan temel yaklaşım gösterilmektedir. Bilgi, iç faktörlerden dış faktörlere doğru bir akış içerisindedir. Şekil 1'e göre, şirketin piyasası, teknoloji kaynağı ve girișim yönetimi ile diğer şirketin pazarı, teknolojisi ve girişim yönetimi arasında bilgi geçiş yapar. Şirket ile çevresi arasındaki sınırın, yeniliklerin ikisi arasında daha kolay hareket etmesini sağlayan gözenekli bir yapıda olduğu görülmektedir. Firma, bu sayede diğer dış paydaşlarla birlikte kolayca paylaşım ve bilgi alışverişinde bulunulabilmektedir (Chesbrough ve Eichenholz, 2013).

Tablo 1 'de açık ve kapalı inovasyonun farklılıkları özetlenmektedir. Açık inovasyon, inovasyon sürecinin gelişiminde son aşamayı oluşturmaktadır. Açı inovasyonun gelişmesindeki en büyük etkiyi gözlemlemek için dijitalleşen firmalar ve teknoloji değeri yüksek ürünlerin üretimini gerçekleștiren işletmeler kullanılmaktadır (Chesbrough vd., 2006:21).

\subsection{Açık İnovasyonda Teknoparkların Rolü}

Açık inovasyonun Ar-Ge faaliyetlerinin iyileștirilmesinde kaldıraç görevi üstenmesi nedeniyle, Ar-Ge konusunda öncü niteliğinde olan teknoparkların açık inovasyon sisteminde önemli rolleri olabilmektedir. İlgili literatürdeki çalışmalara göre, dünya üzerinde açık inovasyona en çok dâhil olan şirketler teknoparklarda yer almaktadır.

Açık inovasyon, iki yönlü olarak fikri mülkiyet hakları konusunda bilgi akışını ve teknoparkların temel paydaşları arasında insan gücünün transfer edilmesi süreçlerinde önemli bir rol oynamaktadır. Açı inovasyon; teknoparklar, üniversiteler, araştırma laboratuvarları, girişimciler, KOBİ'ler ve büyük şirketler arasında çok yönlü bir bağlayıcı faktör olabilmektedir (Narasimahalu, 2013:8).
Teknoloji geliștirme bölgeleri tarafından düzenlenen çeşitli işbirliği toplantıları, teknoloji geliştirme bölgesinde yer alan işletmelerin fikri mülkiyet haklarında sahip oldukları değerleri lisanslayarak ticarileştirmelerine olanak sağlamaktadır. Ticarileşme ve lisanslama faaliyetleri, teknoloji geliştirme bölgelerinde açlk inovasyonu teşvik edici hamleler yaratacaktır. Silikon vadisindeki en önemli başarı faktörlerinden birisi, insan gücünün bir işletmeden diğer işletmeye serbest olarak değişimine teşvik ederek onları istihdam edecek işletmelerin kazanç sağlamalarına olanak tanımaktır (Narasimahalu, 2013:6).

Teknoparklar tarafından ülkemizde uygulanmakta olan dört yönlü model Şekil 2 'de gösterilmektedir. $\mathrm{Bu}$ model üniversite araştırmacılarını, büyük şirketleri, araştırma laboratuvarı altyapılarını ve girişimcileri bir araya getiren bir sarmaldan oluşmaktadır. İşbirliği modeli sayesinde tüm aktörler ilgili ekosistem yapısından yararlanabilmektedir. Açık inovasyon konusunda güncel yaklaşımlar, işletmeler arasındaki işbirliklerinin açık inovasyon sürecine dâhil edilmesine firsat sunmaktadır.

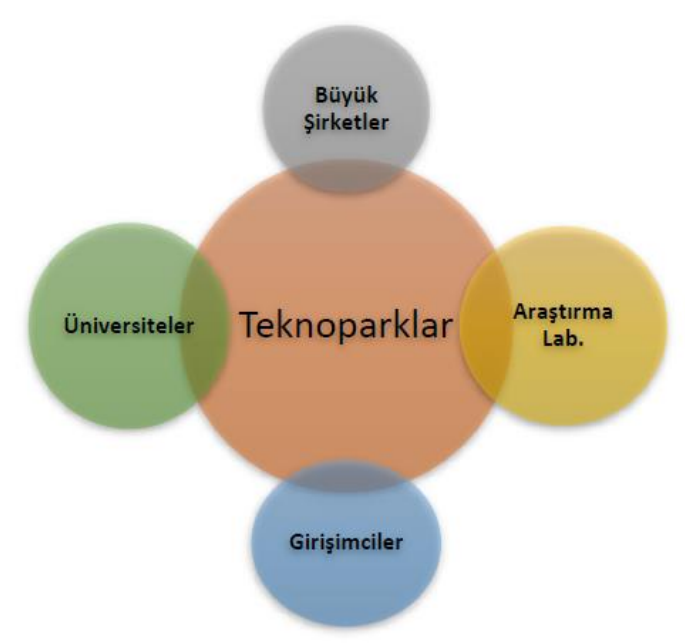

Şekil 2: Teknoparklar Açısından Açık İnovasyon Modeli (Narasimahalu, 2013:7)

Açık inovasyon işbirlikleri sonucunda pazara sunulacak yenilik içeren ürünlerin tüm sektörlerin gelişmesine katkı sağlaması amaçlanmaktadır. Teknolojik ürün pazarında rekabet çok hızlı ve kesintisizdir. Açık 
inovasyon yöntemi sayesinde daha özgün ürünler pazarda yer alma fırsatı bulmaktadır (Pado, 2016:138).

\section{TÜRKIYE'DEKİ TEKNOLOJİ GELISSTİRME BÖLGELERİ}

Dünya üzerinde TGB'lerin gelişimine bakıldığında 65 yıllık bir gelişim ve kurulum süreci bulunmaktadır. Türkiye'nin TGB'ler konusunda bu süreçte oldukça geri kaldığı görülmektedir. $\mathrm{Bu}$ gecikmenin başlıca nedenleri arasında; üniversite sanayi işbirliği alanında yeterli işbirliğinin bulunmaması, ArGe faaliyetlerinin ileri teknoloji konusunda geri düzeyde kalması, politika üreticilerin teşvikler ve kanunlar konusunda yavaş hareket etmesi sıralanabilir. Türkiye'de TGB'lerin kuruluş çalışmalarına başladığı döneme bakıldığında yaklaşık 39 yıllık bir geçmişi olduğu görülmektedir (Alkibay vd., 2012).

Türkiye'de TGB'ler ilk defa 1980'li yıllarda gündeme gelmiş ve sonrasında Devlet Planlama Teşkilatı tarafından oluşturulan kalkınma planlarında yer verilmeye başlanmıștır. 1980'li yıllardan itibaren; yüksek teknoloji düzeyi içeren işletmelerin oluşturulması, yenilikçi işletmelerin teknoloji olgunluk düzeylerinin artırılması, akademik girişimcilerin ortaya çlkarak bu bilgiyi ticarileştirmelerinin sağlaması, bilgilerin sanayiye aktarılması sonucu değer yaratılması amacı ile çalışmalar başlamıştır (Tunca ve Keleş, 2009:316).
Ülkemizde ilk şirket statüsündeki teknoparkın kurulması 10 Mayıs 1988 tarihinde İzmir'de gerçekleşmiştir. 86 kurucu ortağın yer almakta olduğu İzmir Teknopark A.Ș. (İTAŞ) adı ile kurulmuştur. Ege üniversitesi kampüsü içinde yer alması planlanan bu yapı, sanayideki gelişimin hızlanması, girişimciye test ve deneme hizmetlerinin verilmesi için kurulmuştur. Fakat şirketin oluşturulması sonrası yapı işlevsellik kazanamamıştır (Harmancl ve Önen, 1999:29). "Teknoloji Geliştirme Bölgesi; yeni veya ileri teknolojide mal ve hizmet üretmek isteyen girişimcilerin, araștırmacı ve akademisyenlerin sınaî ve ticari faaliyetlerini üniversitelerin yanında veya yakınında yürütebilmelerine ve bu üniversitelerden yararlanabilmelerine imkân vermek için kurulmuş akademik, sosyal ve kültürel sitelerdir." (T.C. Sanayi ve Teknoloji Bakanlığı, 2019). Teknoloji Geliştirme Bölgeleri'nin kuruluşu ülkemizde 4691 sayılı Teknoloji Geliştirme Bölgeleri Kanunu, 06 Temmuz 2001 tarihli ve 24454 sayılı kanun ile gerçekleşmiş olup 36 farklı ilde faaliyet göstermektedir. 2019 yılı itibari ile ülkemizde 83 adet tescil edilmiş teknoloji geliştirme bölgesi yer almakta olup Şekil 3'te gösterilmiştir. $\mathrm{Bu}$ bölgelerin 63 tanesi aktif olarak faaliyetlerini sürdürmektedir. İlgili bölgelerden 20 tanesi tescil edilmiş olup, yapısal oluşumlarına ilişkin yasal süreçleri devam etmektedir.

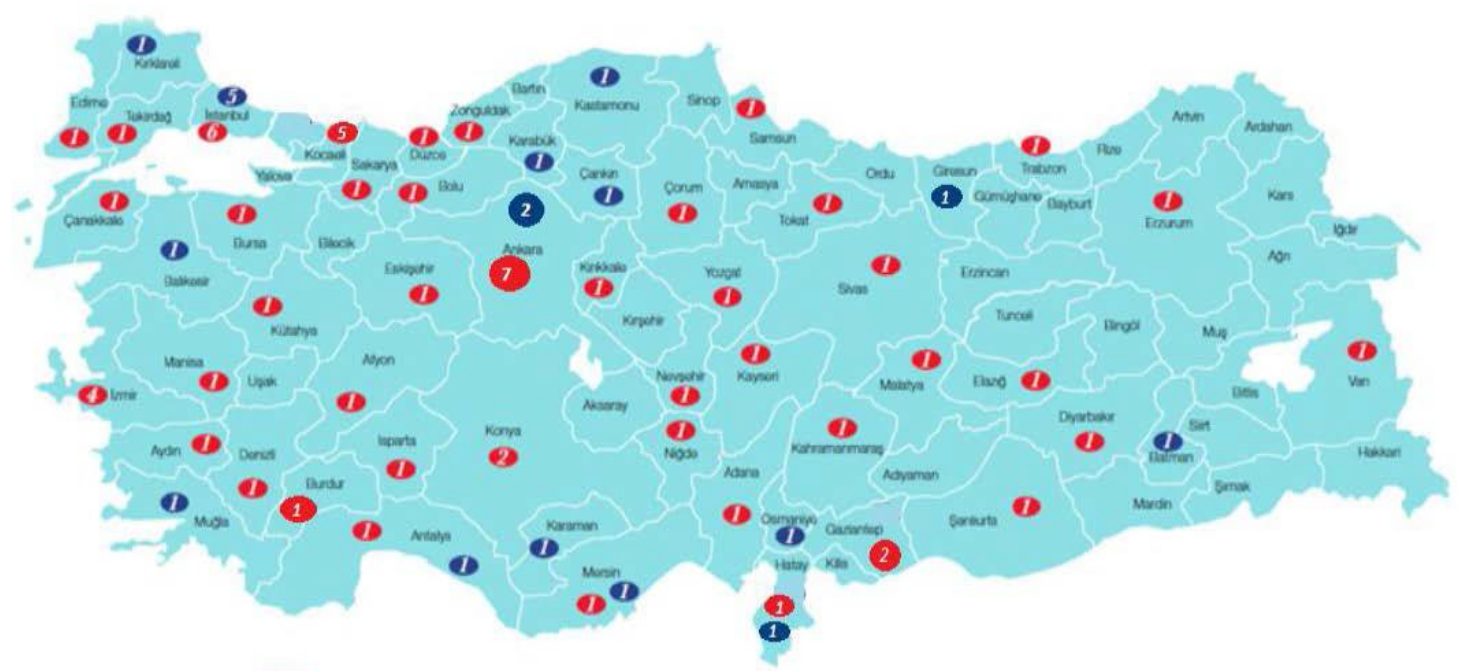


Şekil 3: Faal Teknoloji Geliştirme Bölgelerinin Haritası (San. ve Tekn. Bakanlığı, 2019)

Türkiye'deki TGB’lerde 37.072 Ar-Ge personeli aktif olarak çalışmaktadır. İlgili personelin çalıștığı bölgelerde Şubat 2018 tarihi itibariyle 35.318 adet Ar-Ge niteliği taşımakta olan projeler işletmeler tarafından yürütülmekte olup 3,4 milyar ABD doları tutarında ihracat gerçekleștirilmiştir. Ayrıca, bu bölgelerde 281 adet yabancı sermayeli ve ortaklı şirket faaliyet göstermektedir (Erbay ve Arkan, 2019:704).

Uygulamaya konu olan İzmir bölgesinde ise, Dokuz Eylül Teknoloji Geliştirme Bölgesi, Ege Teknoloji Geliştirme Bölgesi, İzmir Bilim Park, İzmir Yüksek Teknoloji Geliştirme Bölgesi aktif olarak faaliyet gösteren teknoparklardır. Türkiye'nin sağlık alanında yer alan tek sağlık ihtisas teknoparkı DEPARK bölgesinde yer almaktadır.

\section{UYGULAMA}

$\mathrm{Bu}$ çalışma kapsamındaki uygulama DEPARK bölgesinde gerçekleştirilmiştir. DEPARK yönetici şirketi olan "Dokuz Eylül Teknoloji Geliştirme Anonim Şirketi", 3 Ocak 2013 tarihinde 28517 numaralı resmî gazetede yayınlanan kuruluşu tamamlanmıştır. DEPARK, $27.900 \mathrm{~m}^{2}$ alan üstüne kurulmuş olup farklı iki yerleşkede hizmet vermektedir. Bu yerleşkeler Buca, İzmir DEÜ Tınaztepe kampüsünde bulunmakta olan TGB-1 ve Narlıdere, İzmir bölgesindeki DEÜ İnciraltı kampüsünde bulunmakta olan TGB-2'den oluşmaktadır. İlgili bölgeye ilişkin alan dağılımları aşağıdaki tabloda belirtilmiştir.

DEÜ Tınaztepe Yerleşkesi İzmir ili çevre otoyolunun yanında, Aydın otoyolu kavşağının bulunduğu yerde olması nedeniyle, Dokuz Eylül TGB-1 bölgesinden Adnan Menderes Havaalanına, Ege Serbest Bölgesine, İzmir limanına ve Dokuz Eylül TGB-2 bölgesine 15 dakika içinde ulaşmak mümkün olmaktadır. İzmir çevre otoyolu ile bağlı olan Dokuz Eylül TGB-1 ve TGB-2 bölgeleri, İzmir çevresindeki ana ulaşım ağına bağlı yollar sayesinde İzmirÇeşme otoyolu üzerinden IYYTE Teknopark İzmir, İzmir-Aydın otoyolu üzerinden Ekonomi Üniversitesi İzmir Bilim Parkı, İzmir çevre yolu üzerinden Ege Üniversitesi Teknopark Ege ve Manisa Celal Bayar Üniversitesi teknoloji geliştirme bölgelerine kolayca ulaşılabilir bir konumda yer almaktadır.

Tablo 2: TGB Alanı ve Çevresi (DEPARK, 2019)

\begin{tabular}{|l|r|}
\hline $\begin{array}{l}\text { TGB-1 Buca DEÜ Tınaztepe } \\
\text { TGB-2 Balçova DEÜ } \\
\text { Inciraltı }\end{array}$ & $\begin{array}{r}\text { Alan } \\
\mathbf{( 2 0 1 9} \\
\text { Yılı) }\end{array}$ \\
\hline TGB'nin toplam alanı & $27000 \mathrm{~m}^{2}$ \\
\hline $\begin{array}{l}\text { Bölgenin toplam yapılaşma } \\
\text { alanı (kapalı alan, kapalı } \\
\text { otopark hariç) }\end{array}$ & $6740 \mathrm{~m}^{2}$ \\
\hline $\begin{array}{l}\text { Teknopark firmalarının ofis } \\
\text { için kiralayabileceği toplam } \\
\text { alan }\end{array}$ & $3672 \mathrm{~m}^{2}$ \\
\hline $\begin{array}{l}\text { Ön kuluçkaya ayrılan toplam } \\
\text { alan }\end{array}$ & $100 \mathrm{~m}^{2}$ \\
\hline $\begin{array}{l}\text { Kuluçkaya ayrlan toplam } \\
\text { alan }\end{array}$ & $200 \mathrm{~m}^{2}$ \\
\hline $\begin{array}{l}\text { Toplam sosyal hizmet alanı } \\
\text { (Kapalı alan) }\end{array}$ & $2500 \mathrm{~m}^{2}$ \\
\hline $\begin{array}{l}\text { Toplam sosyal hizmet alanı } \\
\text { (Açı alan) }\end{array}$ & $2000 \mathrm{~m}^{2}$ \\
\hline
\end{tabular}

DEÜ TGB 2018 yılı sonu itibari ile gelişmeye ve büyümeye devam eden dinamik bir teknoloji geliştirme bölgesidir. Hâlihazırda yaklaşık \% 98 doluluk oranı seviyesinde 127 adet şirkete ev sahipliği yapmaktadır. Bölgede yer almakta olan şirketlerin 54 tanesi yazılım sektöründe faaliyet göstermektedir. İlgili orandan anlaşılacağı üzere teknoparkın \% 42,52'si yazılım sektöründe faaliyet göstermekte olan firmalardan oluşmuştur.

\section{AMAÇ, KAPSAM VE YÖNTEMLER}

DEPARK bölgesinde açlk inovasyonun etkisini görmek ve açık inovasyon yöntemlerini uygulayarak çalışan işletmeleri incelemek amacı ile" JSIC - Facilitating Open Innovation, Landscape and Feasibility Study" isimli çalışmada uygulanmış olan anket çalışması Türkçe' ye çevrilerek DEÜ TGB'de yapısal olarak en fazla faaliyet göstermekte olan yazılım sektöründe çalışan işletmelere 
uygulanmıștır (JSIC, 2009). DEPARK A.Ş. genel müdürlüğünden ve çalışmanın örnek alındığı kuruluştan gerekli izinlerin alınması sonrasında 9 Kasım 2018 tarihi ile uygulamaya başlanmıştır. 9 Kasım 2018 tarihinde DEÜ TGB'de yer alan firma sayısı 127'dir.

DEÜ TGB bünyesinde yer alan işletmelerin sektörel dağılımı Şekil 4'te gösterilmektedir. Teknoparkımızda sektörel olarak dağılıma bakıldığında yazılım, medikal, bilgisayar ve iletişim teknolojileri yer almaktadır. DEÜ TGB'de \% 42,52 oranı ile yazılım alanında 54 işletme faaliyet göstermekte olup, çalışmamız yazılım sektöründe yer alan bu teknopark işletmelerini kapsayacak şekilde gerçekleștirilmiștir.
Araștırmamız kapsamındaki ișletmelerin açık inovasyona katılımlarını analiz edebilmek için anketimiz sadece işletmedeki proje yöneticileri ya da üst düzey yöneticilere uygulanacak şekilde iletilmiștir. Dijital anket toplama aracı olan Google doküman yönetim sistemi ile hazırlanmış olup ilk etapta e-posta yolu ile DEPARK A.Ş. yönetici şirket aracılı̆̆ ile gönderilmiştir. Geri dönüş sağlanamayan işletmelere anket basılı olarak iletilerek birebir görüşmelerle katılımları sağlanmıştır. Toplam 54 işletmenin 43'ü, yani \% 79'unun bu çalışmamıza katılımı sağlanmış, diğer işletmelerden ise bir geri dönüş alınamamıştır.

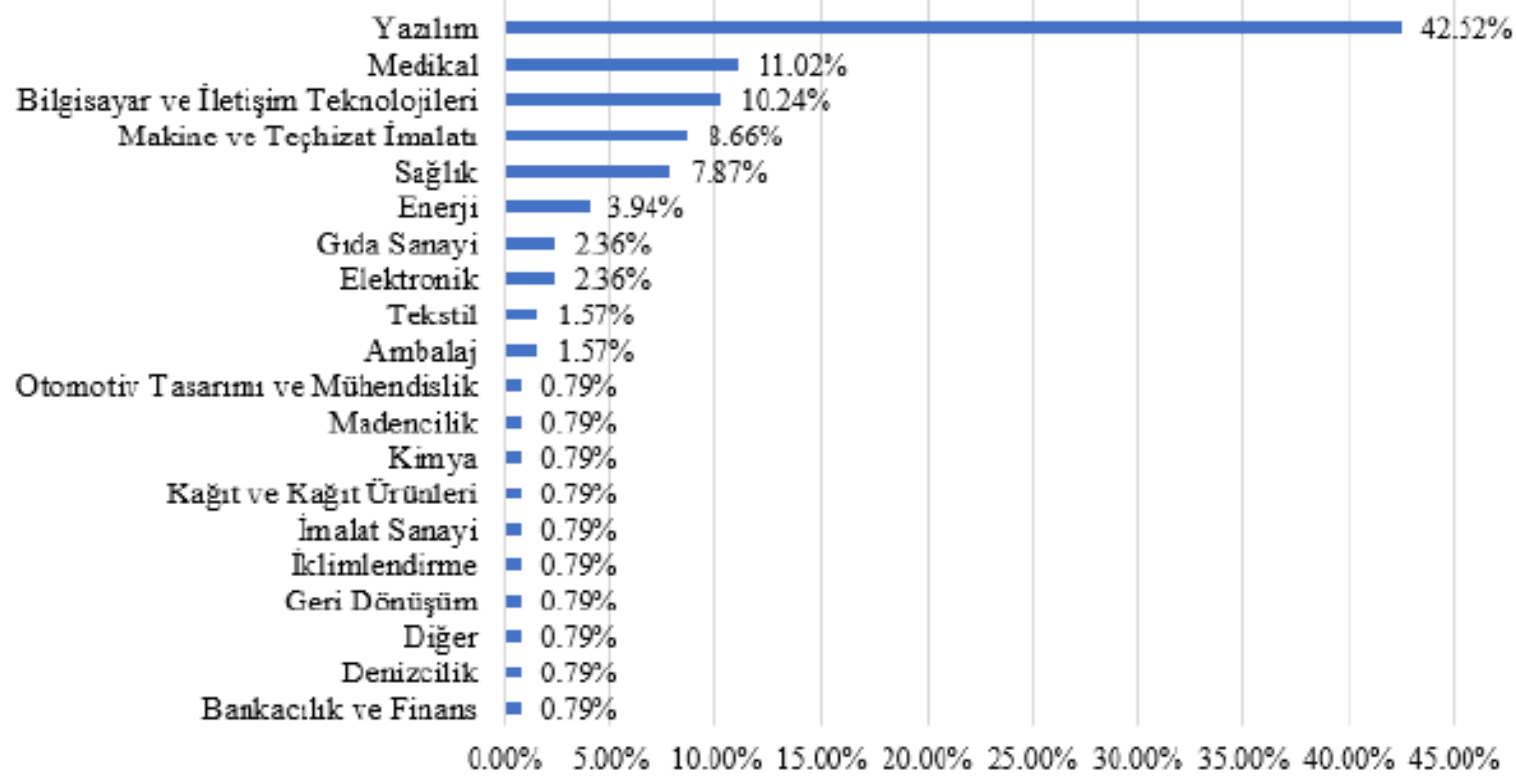

Şekil 4: DEÜ TGB Kasım 2018 Mevcut İşletmelerin Sektörel Dağılımı (DEPARK A.Ş.)

Ankette 19 ana soru bașlığ ve bunların bazılarında da alt başlıklar ve çoklu seçeneklerden oluşan sorular bulunmaktadır. Ankette sorulan soruların bazıları Tablo 3'te örnek olarak gösterilmektedir. Anket çalışmasından gelen sonuç verileri öncelikle Excel formatına aktarılmış ve verilerin düzenli hale getirilmesi sağlanmıștır. Excel ortamından sonrasında SPSS isimli istatistik veri analizi programına aktarımı sağlanmıştır. SPSS yazılımı ile belirlenen analiz yöntemleri ve güvenilirlik analizleri yapılması sağlanmıştır. Sonrasinda uygulanan hipotez testleri ve frekans değerleri ile açık inovasyonun ilgili teknoloji geliştirme bölgesinde durumu değerlendirilmeye çalıșılmıştır.

Katılımcılara yöneltilen sorulardan birisi şirketlerin açık inovasyon kullanma kararı almadan önceki endișe ve çekince durumlarına ilişkin olup, bu soruya ilișkin sonuçlar Şekil 5 'te gösterilmektedir. Şekil 5 incelendiğinde, 
ișletmelerin genel olarak endișe durumlarının proje yönetimi ve yönetimsel zorluklar, zaman kısıtlayıcıları, etkileşimde bulunulmak istenen çalışanlarla olan kültürel farklılıklar, maliyetler, fikri mülkiyet hakları (IP) konusunda endișeli oldukları gözlemlenmiştir. En fazla endişe durumunun ise projelere katılacak doğru kişileri bulma yetisi alanında olduğu gözlemlenmiştir.

Tablo 3: Ankette Kullanılan Sorulardan

\section{Bazları}

\begin{tabular}{|l|l|}
\hline $\begin{array}{l}\text { S3. Aşağıdaki açık inovasyon modellerinden } \\
\text { hangisini daha önce uyguladınız? (çoklu seçim } \\
\text { yapılabilir) }\end{array}$ \\
\hline 1 & Stratejik işbirliği \\
2 & Açık Kaynak \\
3 & Lisanslama \\
4 & Alt geliştirici ile işbirliği \\
5 & Danışmanlık \\
6 & Bilmiyorum \\
7 & Diğer: \\
\hline S4. Hangi iş alanında açık inovasyona katılım \\
sağladınız? (çoklu seçim yapılabilir) \\
\hline 1 & Konsept üretimi \\
2 & Araştırma \\
3 & Geliştirme \\
4 & Tasarım \\
5 & Test \\
6 & İmalat \\
7 & Pazarlama \\
8 & Dağıtım \\
9 & İş Süreçleri Modelleri \\
10 & Lojistik \\
11 & Diğer: \\
\hline$S 7$. Projenin yürütülmesi sırasında, asağıdaki
\end{tabular}

S7. Projenin yürütülmesi sırasında, aşağıdaki alanların her birinden memnuniyet düzeyiniz nedir?

\begin{tabular}{|c|c|c|c|c|c|}
\hline & 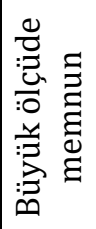 & $\begin{array}{l}\Xi \\
\Xi \\
\Xi \Xi \Xi \\
\Sigma\end{array}$ & 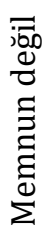 & 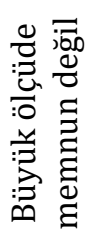 & 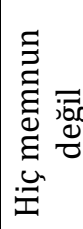 \\
\hline $\begin{array}{l}1 \text { İlgili ortakların } \\
\text { belirlenmesi }\end{array}$ & & & & & \\
\hline $\begin{array}{l}2 \text { Sözleşmesel } \\
\text { pazarlıklar }\end{array}$ & & & & & \\
\hline $\begin{array}{l}3 \text { Proje yönetimi / } \\
\text { idaresi }\end{array}$ & & & & & \\
\hline $\begin{array}{l}\text { 4 Açlk inovasyon } \\
\text { ekibi ile iletişim }\end{array}$ & & & & & \\
\hline 5 Zaman Yönetimi & & & & & \\
\hline
\end{tabular}

\begin{tabular}{|l|l|l|l|l|l|}
\hline $\begin{array}{l}\text { 6 Seçilen takımın } \\
\text { teknik } \\
\text { yeterlilikleri }\end{array}$ & & & & & \\
\hline 7 Maliyet & & & & & \\
\hline $\begin{array}{l}\text { 8 Fikri Mülkiyet } \\
\text { Hakları (IP) } \\
\text { Yönetimi }\end{array}$ & & & & & \\
\hline
\end{tabular}

Anketteki bir başka soru da, işletmeler bazında projelerin yürütülmesi sırasındaki memnuniyet düzeyleri olup ilgili sonuçlar Şekil 6' da gösterilmektedir. İşletmelerin genel olarak yer almakta olan fikri mülkiyet hakları (IP) yönetimi, maliyet, seçilen takımın yeterlilikleri, zaman yönetimi, açık inovasyon ekibi ile etkileşim, proje yönetimi/idaresi, sözleşmesel pazarlıklar, ilgili ortakların belirlenmesi maddelerinden memnun oldukları gözlemlenmiştir. İşletmelerin büyük bir bölümünün zaman yönetimi konusunu olumsuz olarak değerlendirdikleri ve zaman yönetimi performansindan memnun olmadıkları ortaya çıkmaktadır. 


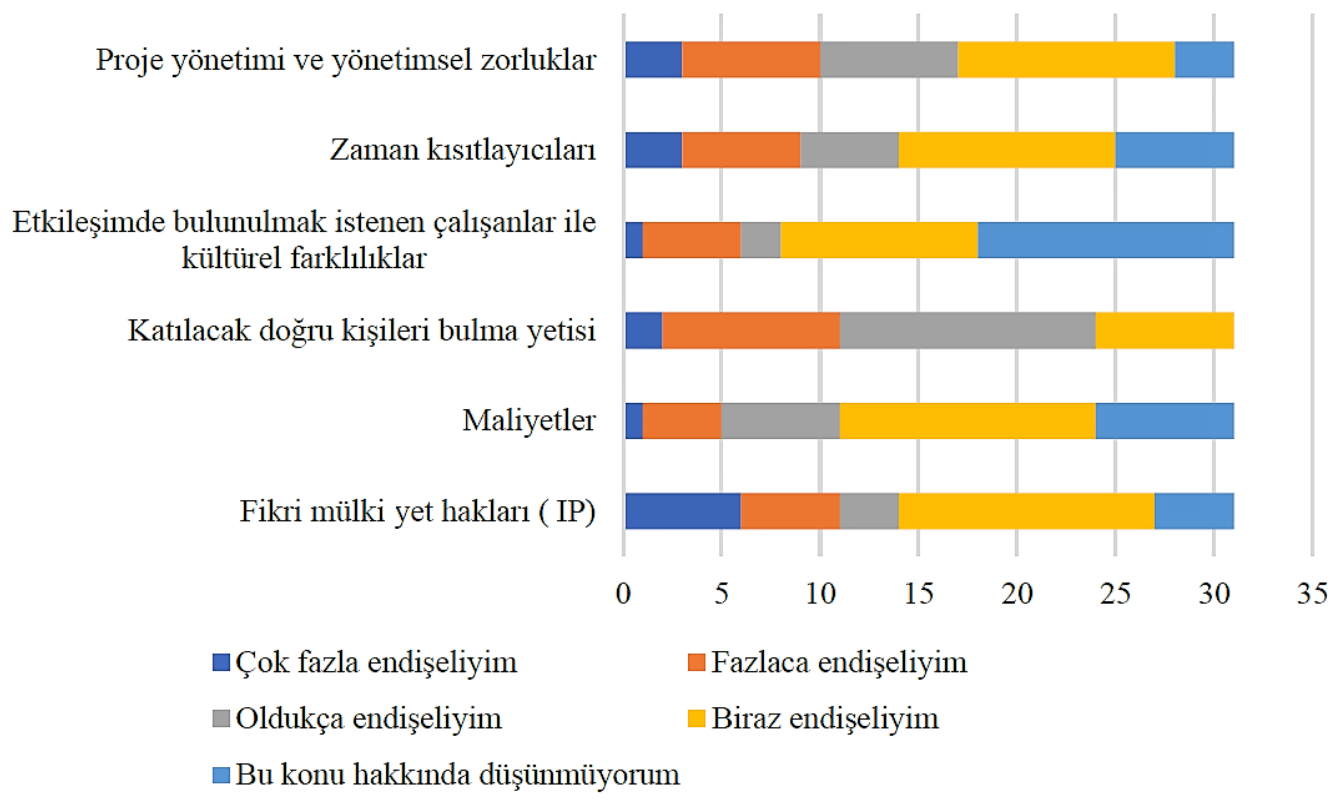

Şekil 5: Açık İnovasyon Kullanım Kararı Öncesi En Büyük Endişe ve Çekince Durumu

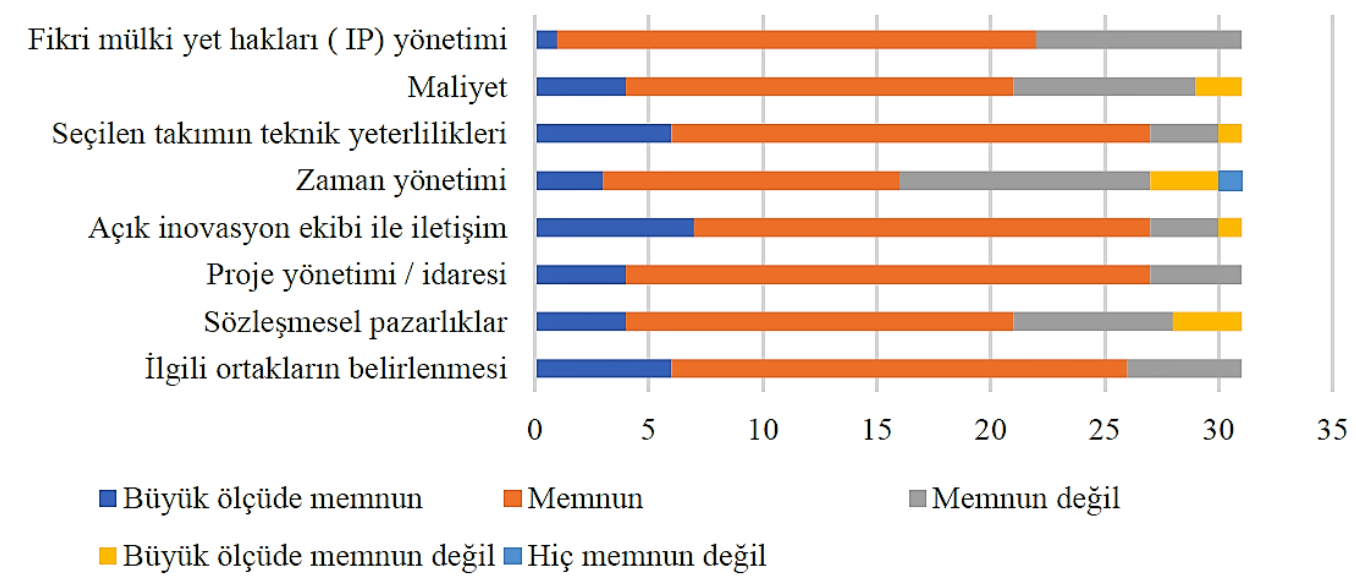

Şekil 6: Proje Yürütülmesi Sırasında İlgili Alanlardaki Memnuniyet Düzeyi

\subsection{Uygulamanın Amacı}

Uygulamanın amacl, teknoparklar odağında açık inovasyonun etkisinin araştırılmasıdır. $\mathrm{Bu}$ kapsamda, dünyada ve Türkiye'de Teknoloji Geliştirme Bölgelerinde yer alan firmaların faaliyet alanlarına bakıldığında en fazla faaliyet gösterilen alan olan yazılım sektöründeki işletmeler ele alınmıştır.

Uygulanan anket çalışmasında ilk etapta işletmelere çalışmanın amacını anlatan kısa bir giriş metni ile bu çalışmanın DEÜ TGB özelinde yapılacağı ve ilgili anket çalışmasının firma yöneticisi, proje yöneticisi, genel müdür gibi üst düzey görevlerde bulunan ve işletmeden yalnızca bir kişinin dolduracağı şeklinde bilgi verilmiștir. Anketin kapsamındaki kurumlar teknoloji geliştirme bölgesinde yer almakta olan işletmeler olarak belirlenmiştir. TGB'de yer almakta olan işletmeler içerisinde en büyük ağırlı̆̆a sahip olan yazılım firmaları seçilerek uygulama bu firmalarda gerçekleştirilmiştir. 9 Kasım 2018 tarihi itibari ile DEÜ TGB'de yer almakta olan 127 toplam firma içinde 54 
yazılım firması belirlenmiș olup bu işletmelerden 43 tanesinden geri dönüş sağlanmıştır. Uygulamada bilgi doğrulanması amacı ile anket sonuçlarında, değerlendirmede kullanılmamak üzere işletme isimlerinin girilmesi istenmiştir. Bu sayede aynı işletmenin birden fazla anket doldurması önlenmiştir.

\subsection{Araştırmanın Kısıtları}

Uygulama tarihi itibari ile 127 adet firmadan en büyük örneklem kümesi 54 yazılım firmasından oluşmaktadır.

Teknopark uygulanan çalışmada eposta, yüz yüze, telefon bilgilendirmesi yöntemleri kullanılmasına ve yönetici şirketin desteklerine rağmen beklenen ilgi gösterilmemiş ve 54 firmadan 43 tanesi dönüş sağlamıştır.

> İşletmelerde genel müdür veya proje yöneticilerine çalışma uygulanmış olup daha alt düzey çalışanlar kapsam dışı bırakılmıştır.

> Açlk inovasyon projesine dâhil olan işletme sayısı bu külte içinde 31 şirket ile sınırlı kalmıştır.

$>$ Genel şirketlerin toplamına bakıldığında ankette sorulan odak grup görüşmesine katılmak isteme durumları sorulmuş ve \% 54 oranında "hayır" olarak yanıtlanmıştır.

\section{BULGULAR}

İşletmelere ilk etapta açık inovasyonun tanımı sorulmuştur. Sonraki soruda açık inovasyon tanımı verilerek daha önce bir açık inovasyon projesinde yer alıp almadıkları tespit edilmiştir. Bundan sonraki aşamadaki sorular açık inovasyon projesine katılım sağlamıș işletmelere doldurmaları sağlanacak şekilde tasarlanmıştır.

\subsection{Güvenilirlik Analizi}

Güvenilirlik değeri bir ölçümde kullanılan ölçüm aracının tekrarlanan ölçümlerde aynı sonucu vermesini sağlamaktadır. Anket oluşturulurken kullanılan sorularda herkesin aynı çıkarımı yapıp yapmadı̆̆ı ya da farklı bir sonuç çıkıp çıkmadığı güvenilirlik analizi ile yapılabilir. Örnek vermek gerekirse, "Düzenli kahve içiyor musunuz?" sorusuna ankette cevap seçenekleri "evet", "hayır" şeklinde olur ise bu sorunun güvenilirlik değeri çok düşük çlkacaktır. Çünkü her insana göre bu yaklaşım farklılık gösterebilmektedir. Güvenilirlik değerinin yüksek olması için anket sorularına verilen cevapların geliştirilmesi gerekmektedir.

Yapılan anketin güvenilirlik skoru Tablo 4'te görüldügü gibi 0,761 olarak elde edilmiştir. Analiz yapıldığında sorulara verilen yanıtlar üzerinden hesaplanan Cronbach Alpha değeri 0,7'den büyük çıktığından dolayı anket güvenilirdir sonucuna varılabilmektedir.

Tablo 4: Anket Güvenilirlik Analizi Sonucu

\begin{tabular}{|c|c|c|}
\hline $\begin{array}{c}\text { Alfa Değeri } \\
(\alpha)\end{array}$ & $\begin{array}{c}\text { Standart. } \\
\text { Madde } \\
\text { Sayısına göre } \\
\text { Alfa Değeri } \\
(\alpha)\end{array}$ & $\begin{array}{c}\text { Kullanılan } \\
\text { Madde } \\
\text { Sayısı }\end{array}$ \\
\hline 0,761 & 0,803 & 18 \\
\hline
\end{tabular}

\subsection{Ki-kare Bağımsızlık Testi}

Ki-kare bağımsızlık testi ile üç farklı hipotez oluşturulmuştur. Bu oluşturulan hipotezler tek tek test edilerek aşağıdaki bulgulara rastlanmiştır. Hücrelerin beklenen değerleri beșten küçük olduğu durumlarda kategoriler birleştirilerek Fisher Kesin Olasılık Testi kullanılmıştır.

Hipotez1: Açık inovasyon projesine dâhil olma durumu ile şirketin faaliyet alanı arasında ilişki vardır.

Hipotez2: Açlk inovasyon uygulamalarındaki memnuniyet düzeyi ile şirketin faaliyet alanı arasında ilişki vardır.

Hipotez3: Açlk inovasyon uygulamalarındaki memnuniyet düzeyi ile gelecekte başka bir açlk inovasyon projesine katılma düşüncesi arasında ilişki vardır.

\section{Hipotez1:}

H0: Açlk inovasyon projesine dâhil olma durumu ile şirketin faaliyet alanı arasında ilişki yoktur. 
H1: Açlk inovasyon projesine dâhil olma durumu ile şirketin faaliyet alanı arasında ilişki vardır.

Hipotez1'e ilişkin olarak ki-kare bağımsızlık test sonucunda elde edilen frekans değerleri Tablo 5'te ve test sonuçları da Tablo 6'da yer almaktadır.

Tablo 5: Alternatif ki-kare Bağımsızlık Test Sonucu Frekans Değerleri

\begin{tabular}{|c|c|c|c|c|}
\hline & \multicolumn{2}{|c|}{$\begin{array}{c}\text { Şirketin Faaliyet } \\
\text { Alanı }\end{array}$} & \multirow[b]{3}{*}{ Toplam } \\
\hline & & Yaratıcı & Bilgi & \\
\hline & & $\begin{array}{c}\text { Endüstr } \\
\text { iler }\end{array}$ & $\begin{array}{c}\text { Teknolo } \\
\text { jileri }\end{array}$ & \\
\hline \multirow{2}{*}{$\begin{array}{l}\text { Açık İnovasyon } \\
\text { Projesine Dâhil } \\
\text { Olma Durumu }\end{array}$} & Evet & 14 & 17 & 31 \\
\hline & Hayır & 4 & 8 & 12 \\
\hline Toplam & & 18 & 25 & 43 \\
\hline
\end{tabular}

Tablo 6: Alternatif ki-kare Bağımsızlık Test Sonucu

\begin{tabular}{|c|c|c|c|}
\hline & Değer & $\mathrm{df}$ & $\begin{array}{c}\text { Asimp. } \\
\text { Anlamlılık } \\
\text { (2-Yönlü) }\end{array}$ \\
\hline Fisher K. O. Testi & & & 0,731 \\
\hline Pearson Ki-Kare & $0,497 a$ & 1 & 0,481 \\
\hline Benzerlik Oranı & 0,130 & 1 & 0,718 \\
\hline Doğrusal Kural & 0,505 & 1 & 0,477 \\
\hline Pearson Ki-Kare & 0,486 & 1 & 0,486 \\
\hline $\begin{array}{l}\text { Geçerli Değişken } \\
\text { Sayısı }\end{array}$ & 43 & & \\
\hline
\end{tabular}

Şirket faaliyet alanı kategorileri yakın olan faaliyet alanları birleștirilerek hesaplanan Fisher Kesin Olasılık Testi anlamlılık değeri $p=$ 0,731 çıkmıştır. $\mathrm{Bu}$ değer 0,731>0,05 değerinden büyük olduğu için HO ifadesini desteklediği kabul edilmektedir. Yani Açık inovasyon projelerine katılım ile şirketlerin faaliyet alanı arasında bir ilişki görülmemektedir.

\section{Hipotez2:}

H0: Açlk inovasyon uygulamalarındaki memnuniyet düzeyi ile şirketin faaliyet alanı arasında ilişki yoktur.
H1: Açık inovasyon uygulamalarındaki memnuniyet düzeyi ile şirketin faaliyet alanı arasında ilişki vardır.

Hipotez2'e ilişkin olarak ki-kare bağımsızlık test sonucunda elde edilen frekans değerleri Tablo 7'de ve test sonuçları da Tablo 8'de yer almaktadır.

Tablo 7: Ki-kare Bağımsızlık Test Sonucu Frekans Değerleri

\begin{tabular}{llc|c|c} 
& & $\begin{array}{c}\text { Yaratıcl } \\
\text { End. }\end{array}$ & $\begin{array}{c}\text { Bilgi } \\
\text { Tek. }\end{array}$ & Toplam \\
\hline $\begin{array}{l}\text { Açık } \\
\text { inovasyon } \\
\begin{array}{l}\text { uyg. memn. } \\
\text { düzeyi }\end{array}\end{array}$ & Orta & 14 & 12 & 26 \\
\cline { 2 - 5 } & Yüksek & 4 & 9 & 13 \\
\hline \begin{tabular}{l} 
Toplam \\
\hline
\end{tabular} & & 18 & 21 & 39 \\
\hline
\end{tabular}

Tablo 8: Ki-kare Bağımsızlık Test Sonucu

Asimp.

Anlamlılık

Değer df (2-Yönlü)

\begin{tabular}{lc|c|c}
\hline Fisher K. O. Testi & & & 0,307 \\
\hline Pearson Ki-Kare & 1,857 a & 1 & 0,173 \\
\hline Benzerlik Oranı & 1,897 & 1 & 0,168 \\
\hline Doğrusal Kural & 1,810 & 1 & 0,179 \\
\hline $\begin{array}{l}\text { Geçerli Değişken } \\
\text { Sayısı }\end{array}$ & 31 & & \\
\hline
\end{tabular}

Uygulanan Fisher Kesin Olasılık Testi anlamlılık değeri $p=0,307$ çıkmıştır. Bu değer 0,337>0,05 olduğu için H0 ifadesini desteklemektedir.

\section{Hipotez 3:}

H0: Açlk inovasyon uygulamalarındaki memnuniyet düzeyi ile gelecekte başka bir açık inovasyon projesine katılma düşüncesi arasında ilişki yoktur.

H1: Açık inovasyon uygulamalarındaki memnuniyet düzeyi ile gelecekte başka bir açık inovasyon projesine katılma düşüncesi arasında ilişki vardır.

Hipotez3'e ilişkin olarak ki-kare bağımsızlık test sonucunda elde edilen frekans değerleri Tablo 9'da ve ilgili test sonuçları da Tablo 10 'da yer almaktadır. 
Tablo 9: Ki-kare Bağımsızlık Test Sonucu Frekans Değerleri

\begin{tabular}{|c|c|c|c|c|}
\hline & & \multicolumn{2}{|c|}{$\begin{array}{c}\text { Gelecekte } \\
\text { başka bir açık } \\
\text { inov. proj. } \\
\text { katılma } \\
\text { düşüncesi }\end{array}$} & \multirow[b]{2}{*}{ Toplam } \\
\hline & & Evet & Olası & \\
\hline \multirow{2}{*}{$\begin{array}{l}\text { Açlk } \\
\text { inovasyon } \\
\text { uyg. memn. } \\
\text { düzeyi }\end{array}$} & Orta & 10 & 10 & 20 \\
\hline & Yüksek & 9 & 2 & 11 \\
\hline Toplam & & 19 & 12 & 31 \\
\hline
\end{tabular}

Tablo 10: Ki-kare Bağımsızlık Test Sonucu

Asimp.

Anlamlılık

\begin{tabular}{lr|r|r} 
& Değer & df & (2-Yönlü) \\
\hline Fisher K. O. Testi & & & 0,093 \\
\hline Pearson Ki-Kare & 3,337 a & 1 & 0,068 \\
\hline Benzerlik Oranı & 3,488 & 1 & 0,062 \\
\hline Doğrusal Kural & 3,251 & 1 & 0,071 \\
\hline $\begin{array}{l}\text { Geçerli Değişken } \\
\text { Sayısı }\end{array}$ & 31 & & \\
\hline Fis & & & \\
\hline
\end{tabular}

Fisher Kesin Olasılık Testi anlamlılık değeri $\mathrm{p}=$ 0,093 çıkmıştır. Bu değer çok yüksek olmasa da, 0,093>0,05 olduğu için H0 ifadesini desteklediği söylenebilir.

Çalışmamızda kullanılan örneklem sayısı ve geri dönüş sayısı yeterli görülmekle birlikte çalışma sonuçlarının alternatif bir yöntemle test edilmesi planlamıștır. Bu kapsamda veri madenciliğindeki birliktelik kural analizi yöntemi seçilmiştir.

\subsection{Birliktelik Kural Analizi ve Apriori Algoritması}

Veri madenciliği, anlamsız, büyük veri yığınlarından, geçerli ve kullanışlı, anlamlı örüntüleri çıkarmak için kullanılan birçok metot, tekniklerin ve yöntemlerin bütünüdür. Veri madenciliğinde önemli olan önceden elde edilememiş, anlamlandırılamamış verilerin elde edilmesine olanak sağlamasıdır. "Veri madenciliği daha önceden bilinmeyen geçerli ve uygulanabilir bilgilerin geniş veri tabanlarından elde edilmesi ve bu bilgilerin ișletme kararları verirken kullanılmasıdır" (Silahtaroğlu, 2016:8).

Birliktelik kuralı analizi, yaygın kullanılmakta olan veri madenciliği yöntemlerinden birini oluşturmaktadır. Birliktelik kuralı analizi yöntemi ilk kez 1990'lı yılların başında (Agrawal vd., 1999) tarafindan ortaya atılmıștır. Birliktelik kuralı analizi genel olarak bakıldığında "Market Sepet Analizi" olarak adlandırılmaktadır. Birliktelik kuralları, veri kümesindeki kategorik değișkenlerin frekanslarına göre oluşturulur ve "EĞER X=... İSE, $\mathrm{Y}=. . . "$ şeklinde kurallar çıkartılır. Kuralın "İSE" ("THEN") kısmının önünde kalan "EĞER" ("IF") koşuluna uyan değişken(ler) kuralın öncülü, "ISE" kısmının sonrasındaki değişken(ler) ise kuralın ardılıdır. Bir kuralın öncül ve / veya ardılında bir veya birden fazla değişken olabilir ve birden fazla değişken olması durumunda bu değișkenler "VE" mantıksal işlemiyle bağlanır. Birliktelik kurallarında sadece kategorik değişkenler kullanılabilir, sayısal değişkenler kullanılamaz.

Birliktelik kuralı analizinde en sık kullanılan algoritmalardan birisi Apriori algoritmasıdır. Apriori algoritmasında temel çalışma prensibi eğer $n$ tane değişkeni içeren bir $K$ kümesi, minimum destek değeri koşulunu sağlıyorsa bulunmakta olan kümenin alt kümeleri de bu destek değeri koşuluna kesin olarak uymaktadır. Kümeler hazırlanırken veri tabanı taranır. Sık tekrarlanmakta olan kümelerin bulunmasının amaçlandığı Apriori minimum destek koşulu sağlanan kümeleri bulur. $\mathrm{Bu}$ bulunan kümeler daha geniş öğe kümeleri oluşturulmasında kullanılır (Witten vd., 2011). Kayıt / örnek sayısının az olması nedeni ile klasik istatistiksel yöntemlerle sonuç alınmayan ya da tartışmalı sonuç verecek durumlarda, alternatif olarak birliktelik analizi ve Apriori algoritmasının kullanılması önerilmektedir (Han ve Kamber, 2006; Witten vd., 2011).

$\mathrm{Bu}$ çalışmada, Apriori algoritmasıyla elde edilen birliktelik kurallarının seçimi ve sıralamasında kullanılan ölçüm yöntemleri kısaca bu kısımda açıklanmıştır. Support 
(Destek) ve Confidence (Güven) bunlardan en bilinen iki tanesidir. Destek oranı bir kuralın, toplam kayıt sayısının kaçta kaçında geçerli olduğunu göstermektedir ve 0 ile 1 arası değerler alabilir. Güven değeri ise bu kuralın kendi içindeki güvenilirlik değerini göstermektedir ve 0 ile 1 arası değerler alabilir (Han ve Kamber, 2006). Güven değeri, kuralın Destek sayısının kuralın öncül kısmına uyan kayıt sayısına oranıdır. Lift (İlginçlik) değeri ise kuralın özgünlüğü / farklılığını ifade etmektedir ve Destek değerinin Güven değerine bölünmesiyle hesaplanır. İlginçlik değeri, 0 ile artı sonsuz arası değerler alabilir. Leverage (Kaldıraç) değeri de, bir kuralın öncül ve ardıl kısımlarındaki değişkenler arasındaki bağın kuvveti olarak belirtilmektedir ve $-0,25$ ile 0,25 arası değerler alabilir (Witten vd., 2011). $\mathrm{Bu}$ dört yöntem yanı sıra, birliktelik kuralları için genelde daha az kullanılan başka ölçüm yöntemleri de bulunmaktadır. Bu çalışmada seçilen ve kullanılan bu dört yöntemin matematiksel tanımlamaları $1,2,3$ ve 4 numaralı denklemlerde gösterilmiștir.

$$
\begin{aligned}
& \begin{array}{l}
\text { A ve } B \text { değişkenleri için aşă̆ } \text { daki birliktelik kuralını varsayalım; } \\
\qquad I F \quad\{A\} \Rightarrow\{B\}
\end{array} \\
& \text { Support }=P(A \cap B)=\frac{A \text { ve } B^{\prime} \text { nin her } \text { ikisini de içeren kayıtlar }}{\text { veri seti }} \\
& \text { Confidence }=P(B \mid A)=\frac{P(A \cap B)}{P(A)} \\
& \text { Lift }=\frac{P(A, B)}{P(A) \cdot P(B)}=\frac{P(A \cap B)}{P(A) \cdot P(B)} \\
& \text { Leverage }=P(A, B)-P(A) \cdot P(B)=P(A \cap B)-P(A) \cdot P(B)
\end{aligned}
$$

Anket uygulaması sonucunda ortaya çıkan verilere klasik istatistik yöntemleri uygulanmıştır. Klasik istatistik yöntemleri sonrasında daha anlamlı sonuçlar elde etmek amacı ile birliktelik kuralı analizi yapılması amaçlanmıştır. WEKA yazılımında bulunan Apriori algoritması ile birliktelik kuralı analizi gerçekleștirilmiştir. WEKA yazılımı, veri analizi, veri madenciliği ve yapay öğrenme alanlarında kullanılan açık kaynak kodlu bir yazılımdır (WEKA, 2019). Waikato üniversitesinde Java programlama dilinde geliştirilmiştir. Birliktelik kuralı analizi yapılırken en yaygın kullanılmakta olan bilgi analiz sistemi yazılımıdır (Veri Bilim Okulu, 2019).

Yapılan denemeler sonucunda tüm kurallar içerisinde seçilecek olan kurallar için eşik değerleri İlginçlik $\geq 2,0$, Kaldıraç $\geq 0,15$, Destek $\geq 0,25$ olarak belirlenmiştir. $\mathrm{Bu}$ değerler ışığında "S2. Açık inovasyon projesine dâhil oldunuz mu?" sorusuna evet yanitı veren işletmeler üstünde analiz çalışması gerçekleştirilmiştir. $\mathrm{Bu}$ analiz sonucunda 22 adet kural ortaya çıkmıştır. Apriori algoritması kullanılarak elde edilen birliktelik kurallarında, Kaldıraç değeri $\geq 0,15$ olanlar filtrelenerek seçilmiş ve bunlar içinde de İlginçlik, Destek ve Güven değerleri en yüksek olanlar sıralanmıştır. Son aşamada da, bu en öncelikli 22 kural içinde iş süreçleri ve yönetsel bakış açısıyla en gerçekçi, geçerli ve uygun olanlar manuel olarak ayırt edilmiş ve nihai aşamada toplam dört adet kural seçilmiştir.

\subsection{Birliktelik Kurallarının Yorumlanması}

Kural 1'e göre: "S3. Kullanılan açık inovasyon modeli $=$ Stratejik iş birliği" ve "S7. Proje yürütme sürecinde sözleșmesel pazarlıklardan memnuniyet düzeyi = Memnun" ve "S7. Proje yürütme sürecinde maliyetlerden memnuniyet 
düzeyi = Memnun" ve "S12. Online portal kullanımı çok kişi kullanmazsa kullanışlı olmayacaktır" seçilmiş ise; o zaman, "S4. Katılım sağlanan açık inovasyon iş alanı = Geliştirme" ve "S7. Proje yürütülmesinde seçilen takımın yeterliliği = Memnun" olacak șekilde bir ilişki / birliktelik vardır.

Kural 1'in ölçüm değerleri: Destek $=0,20$, Güven $=1,00$, İlginçlik $=4,29$, Kaldıraç $=0,15$ olarak ölçülmüştür. Bu kuralın İlginçlik değeri tüm kurallar içerisinde en yüksek olup, aynı zamanda Güven değeri de maksimum düzeyde olduğu için bu kural öncelikle kayda değer ve geçerli olarak görülmüştür. Destek değeri ise 0,20 olup 30 kayıtlık veri seti içindeki toplam 6 kayıt için bu kural geçerlidir.

Kural 10'a göre "S3. Kullanılan açık inovasyon modeli = Stratejik iş birliği" ve "S4. Katılım sağlanan açı inovasyon iş alanı = Geliştirme" ve "S7. Proje yürütme sürecinde sözleşmesel pazarlıklar memnuniyet düzeyi = Memnun" ise; o zaman, "S4. Katılım sağlanan açı inovasyon iş alanı = Tasarım" ve "S7. Proje yürütme sürecinde maliyetlerden memnuniyet düzeyi = Memnun" olacak şekilde bir ilişki / birliktelik vardır.

Kural 10'un ölçüm değerleri: Destek $=0,23$, Güven $=0,88$, İlginçlik $=2,92$, Kaldıraç $=0,16$ olarak ölçülmüştür. Güven maksimuma yakın olduğu ve İlginçlik ve Kaldıraç değerleri de diğer kurallara göre daha yüksek olduğu için kural kayda değer ve geçerli olarak görülebilir. Destek değeri ise 0,23 olup bu kural, veriler içindeki toplam 7 kayıt için geçerlidir.

Kural 13'e göre "S4. Katılım sağlanan açık inovasyon iş alanı = Geliștirme" ve "S7. Proje yürütme sürecinde sözleşmesel pazarlıklar memnuniyet düzeyi = Memnun" ve "S12. Online portal kullanımı çok kişi kullanmazsa kullanışlı olmayacaktır" seçilmiş ise; o zaman, "S7. Proje yürütme sürecinde takımın yeterliliği = Memnun" ve "S7. Proje yürütme sürecinde maliyetlerden memnuniyet düzeyi = Memnun" olacak şekilde bir ilişki / birliktelik vardır.

Kural 13'ün ölçüm değerleri: Destek $=0,33$, Güven $=0,91$, İlginçlik $=2,27$, Kaldıraç $=0,19$ olarak ölçülmüștür. Güven maksimuma yakın olduğu ve İlginçlik ve Kaldıraç değerleri de diğer kurallara göre daha yüksek olduğu için kural kayda değer ve geçerli olarak görülebilir. Destek değeri ise 0,33 olup elde edilen tüm kurallar içinde en yüksek Destek değeridir ve bu kural toplam 10 kayıtta geçerlidir.

Kural 18'e göre "S7. Proje yürütme sürecinde ilgili ortakların belirlenmesi düzeyi = Memnun" ve "S7. Proje yürütme sürecinde fikri mülkiyet hakları yönetimi memnuniyeti = Memnun" ve "S18. Açlk inovasyonla ilgili olarak, gelecekte de sizinle görüşülmesi = Evet" tercih edilmiş ise; o zaman, "S7. Proje yürütme sürecinde sözleşmesel pazarlıklar memnuniyet düzeyi = Memnun" ve "S19. Açık inovasyonla ilgili olarak, gelecekte bir odak grup içinde yer almak istenilmesi = Hayır" olacak şekilde bir ilişki / birliktelik vardır.

Kural 18'in ölçüm değerleri: Destek $=0,26$, Güven $=1,00$, İlginçlik $=3,00$, Kaldıraç $=0,18$ olarak ölçülmüştür. Güven değeri maksimum olduğu ve İlginçlik ve Kaldıraç değerleri de diğer kurallara göre çok daha yüksek olduğu için kural kayda değer ve geçerli olarak görülmektedir. Destek değeri ise 0,26 olup bu kural veriler içindeki toplam 8 kayıt için geçerlidir.

Ortaya çıkan birliktelik kurallarının sıklıkla tekrar edildiği görülmektedir. İlgili değerler ve tekrar eden kurallar çerçevesinde bakıldığında işletmeler arasında anlamlı bir bağ oluşturduğu gözlemlenmektedir.

\section{SONUÇ}

$\mathrm{Bu}$ çalışmada, ilgili literatürün taranması ile elde edilen kuramsal bilgiler ve uygulama sonuçları doğrultusunda DEÜ TGB' de yer alan yazılım şirketlerindeki açık inovasyonun etkisi ve açık inovasyon projelerine katılım düzeyleri analiz edilmiştir. Çalışmaya katılan yazılım şirketlerinin büyük bir bölümünün açık inovasyon projelerinde yer aldığı belirlenmiştir. DEÜ TGB'deki yazılım şirketlerinde açı inovasyon projelerinin kullanımının yaygın olduğu olgusu ortaya konmuştur. Uygulamada kapsam olarak 
teknoloji geliştirme bölgesinde yer almakta olan ve yazılım sektöründe çalışan işletmeler kullanılmıştır. 9 Kasım 2018 Tarihi itibari ile DEPARK bölgesinde yer almakta olan 127 toplam firma içinde 54 işletme belirlenmiş olup bu işletmelerden 43 tanesinden geri dönüş sağlanmıştır. 54 Yazılım sektöründe çalışan işletmeden dönüş yapanların oranı yazılım sektöründeki işletmelerin $\% \quad$ 79'unu oluşturmaktadır.

Açık inovasyon projelerine daha önce katılmış olan tüm işletmelerin gelecekte de bu projelere katılmaya devam etmek isteyeceği sonucu elde edilmiştir. Açık inovasyon projesine katılım sağlamış işletmelerin bu deneyimlerinden memnun kaldıkları gözlemlenmiştir. Katılım sağlanan açık inovasyon projelerinde en büyük problemin, dışarıdan projeye dâhil olacak doğru kişilerinin bulunamaması olduğu görülmüştür.

İşletmelerin, proje yürütülmesi sırasında fikri mülkiyet hakları (IP) yönetimi, maliyet, seçilen takımın yeterlilikleri, zaman yönetimi, açık inovasyon ekibi ile etkileşim, proje yönetimi/idaresi, sözleşmesel pazarlıklar, ilgili ortakların belirlenmesi maddelerinden memnun fakat zaman yönetiminden memnun olmadıkları gözlemlenmiştir.

Çalışmanın birinci sorusunda işletmelerden kendilerine göre açık inovasyonun tanımı yapmaları istenmiştir. Soruyu yanıtlayan işletmelerin \% 42,2'si organizasyon dıșındaki ortak fayda ve kazanç sağlayacak projeler için ortak çaba sarf edilmesi olarak tanımlamışlardır. Diğer yanıtlar içerisinde ise \% 14 oranında "Yenilik içeren aktiviteleri, dâhili bir Ar-Ge birimine gerek duymadan dışarıya taşıyarak çözümlemek ve kendi başımıza çözemediğimiz özel bir problemi danışarak farklı kişiler ile çözümlemek" yer almaktadır. \% 7 oranında katılımcı ise açık inovasyonu fikri hakkın içeri ya da dişarı lisanslanması olarak tanımlamıştır. Çalışmaya katılım sağlayan \% 20,9'luk bir kesim ise açık inovasyonun ne olduğundan emin olmadıklarını belirtmiştir. Katılımcıların büyük bir çoğunluğu, açık inovasyonu organizasyon dışındaki ortak fayda sağlayacak projeler için ortak bir çabanın sarf edilmesi olarak tanımlamıştır. Çalışmamıza katılan işletmelerin $\%$ 72,1' inin açık inovasyon proje deneyimleri olduğu belirlenmiștir. Çalışmada yer alan diğer sorularda bu 31 işletmenin vermiş olduğu yanıtlar üstünden analizler ve çlkarımlar yapılmıştır.

İşletmelere yöneltilen "Hangi iş alanında açık inovasyona katılım sağladınız?" sorusu ile çoktan seçmeli olarak veriler toplanmış olup birden fazla verilen yanıtlarda gruplandırılmıştır. Elde edilen sonuçlara göre stratejik işbirliği ve danışmanlık alanında en fazla katılımın sağlandığı görülmektedir. En az katılım alanı ise lisanslama konusu olmuştur. Ayrıca üç adet işletme hangi iş alanında açık inovasyona katılım sağladığını tam olarak bilmediğini belirtmiştir.

Şirketlerin açık inovasyon kullanma kararı almadan önceki kaygı ve çekince durumlarına bakıldığında proje yönetimi ve yönetimsel zorluklar, zaman kısıtlayıcıları, etkileşimde bulunulmak istenen çalışanlarla olan kültürel farklılıklar, maliyetler, fikri mülkiyet hakları (IP) konusunda biraz kaygılı oldukları gözlemlenmiştir. En fazla endişe durumu ise "Katılacak doğru kişileri bulma yetisi" alanında olduğu gözlemlenmiştir.

Açık inovasyon projesine katılım sağlayan işletmelerin memnuniyet düzeylerini 1-10 arası puanlamaları istenmiştir. İlgili projelere katılım sağlayan işletmeler genel olarak 5-9 arası memnuniyet düzeyinde olduklarını belirtmişlerdir. İşletmeler bazında bakıldığında en yüksek memnuniyet düzeyi 7 olarak gözlemlenmiştir.

Açık inovasyon projelerine katılım sağlayan işletmelere gelecekte başka bir açı inovasyon projesinde yer almak isteyip istemedikleri sorulmuştur. Daha önce açık inovasyon projesi gerçekleştirmiş işletmelerin \% 61,3'ü bu projelere gelecekte kesin olarak tekrar katılmak istediklerini, \% 38,3' lük bir kesim ise muhtemelen katılabilecekleri yanitını vermiştir. $\mathrm{Bu}$ bölümde, projelere gelecekte 
tekrar katılım ile ilgili olumsuz yanıt veren işletme bulunmamaktadır.

Yukarıda belirtilen sonuçları destekleyecek ve doğrulayacak nitelikte Apriori algoritması ile elde edilen 22 adet birliktelik kuralı da bu göstergelerin gerçekçi olduğunu göstermektedir. Detaylı analizler sonucunda dört adet kural seçilmiştir ve bu dört kuralın da, Destek, Güven, İlginçlik ve Kaldıraç değerleri toplam 30 kayıtllk bir veri seti için oldukça yüksek ve güvenilir düzeyde olduğu gözlemlenmiştir. Bu da göstermektedir ki, bu birliktelik kurallarındaki ilgili koşulları sağlayan işletmeler arasında anlamlı bağlantılar bulunmaktadır.

Yapılan çalışma sonucunda yazılım firmalarının \% 20,9'unun açık inovasyon hakkında bir fikri olmadığı sonucuna ulaşılmıştır. Açık inovasyon kültürü ve yaklaşımının yaygınlaşması amacıyla tüm aktörleri (teknoloji transfer ofisleri, TGB yönetimleri, firmalar, gençler vb.) bir araya getirecek farkındalık çalışmalarının gerçekleştirilmesinin önemli olduğu görülmektedir.

Ankete katılan firmalardan açık inovasyon projesine dâhil olan firmaların stratejik işbirliği ve danışmanlık alanında en çok katılım sağladıkları, lisanslama alanında ise en az katılımın olduğu görülmüştür. $\mathrm{Bu}$ sonucun altında yatan asıl nedenin firmaların fikri mülkiyet haklarının korunması konusunda yaşadıkları zorluklar olduğu düşünülebilir. Kanun belirleyicilerin bu konuyla ilgili olarak, mevzuat ve uygulamada yaşanan sorunları çözmeye yönelik önlemler alması son derecede önemlidir.

Çalışmamıza katılan işletmelerin \% 93.5'i, çevrimiçi yapılacak bir web uygulaması ve portalinin çok faydalı olacağını belirtmiștir. Ayrıca, böyle bir web portalinin, çok kişi kullanmadığı sürece kullanışlı olmayacağı görüşü de yer almaktadır. Teknoparklarda yer alan işletmelerin bu tarz bir portala dâhil edilmesi konusunda bazı yasal zorunluluklar getirilerek kullanıma ilişkin isteksizliğin ortadan kalkması sağlanabilir. Katılım sağlanan açık inovasyon projesi öncesi en büyük çekincenin katılacak doğru kişileri bulma yetisi olduğu görülmüştür. Bu yetilerin düzgün bir şekilde ortaya çıkarılacağı çevrimiçi portal modeli Türkiye'deki teknoparkların ortak kullanımına sunularak yerelde ve ülke genelinde bu sorunun önüne geçilmesi sağlanabileceği düşünülmektedir.

Açık inovasyon faaliyetleri, dünya genelinde teknoparklar ve bilim parklarında yaygın olarak sürdürülmektedir. Ülkemizde ise bu faaliyetler henüz gelişme aşamasında olup oldukça sınırlı sayıdadır. Araştırmada yer alan yazılım şirketlerinin bu konudaki bazı görüşleri ve yorumları da bu sorunu ortaya koymaktadır.

Dokuz Eylül Teknoloji Geliștirme Bölgesinde yazılım firmaları ile gerçekleştirilmiş olan bu araștırmayla daha genel sonuçlara ulaşılabilmesi için örneklem kapsamının genişletilerek İzmir'de yer alan bütün teknoloji geliştirme bölgelerine yönelik bir çalışma yapılması önerilmektedir.

Sonuç olarak, DEÜ TGB yer alan yazılım şirketlerinin proje yöneticilerinin açlk inovasyon konusunda bilgi sahibi oldukları görülmektedir. Fakat tüm Ar-Ge personelinin bu konuda bilgi düzeyinin ne durumda olduğu belirsizdir. Çeşitli eğitim çalışmaları sonucunda farkındalığın artmasına katkı sağlanabileceği düşünülmektedir.

\section{REFERANSLAR}

Adair, J. (2015), Yenilikçi Liderlik, Çev. Sedat Uyan, Babali Kültür Yayınları, İstanbul.

Agrawal, R., Imielinski, T. ve Swami, A. (1993), "Mining Association Rules Between Sets of
Items in Large Databases", ACM SIGMOD, 207216.

Alkibay, S., Orhaner, E., Korkmaz, S. ve Sertoğlu, A. (2012), "Üniversite Sanayi İşbirliği Çerçevesinde Teknoparklar, Yönetimsel 
Sorunları ve Çözüm Önerileri”, Atatürk Üniv. İIB Dergisi, 65-88.

Annerstedt, J. (2006), Science Parks and HighTech clustering, International Handbook on Industrial Policy, Patrizio Bianchi ve Sandrine Labory (Eds.), Edward Elgar Publishing.

Basile, A. (2011), "Networking System and Innovation Outputs: The Role of Science and Technology Parks", International Journal of Business and Management, 3-14.

Bessant, J. ve Tidd, J. (2007), Innovation and Entrepreneurship, John Wiley and Sons, Chichester.

Chesbrough, H. (2003), Open innovation the new imperative for creating and profiting from technology, Harward Business School Press.

Chesbrough, H. ve Bogers, M. (2013), "Explicating open innovation: Clarifying an emerging paradigm for understanding innovation", New Frontiers in Open Innovation, 3-28.

Chesbrough, H. ve Eichenholz, J. (2013), Open Innovation: The case for sharing and harvesting innovations in photonics, The International Society for Optics and Photonics.

Chesbrough, H., Vanhaverbeke, W. ve West, J. (2006), Open innovation: Researching a new paradigm, 1st ed., Oxford University Press.

DEPARK. https://www.depark.com/tgbbolgelerimiz, (14.06.2019).

Drucker, P. (1985), "The Discipline of Innovation", Harvard Business Review, 67-72.

Erbay, E. R. ve Arkan, D. (2019), "Teknoparkların Mevcut Durumu”, XI. IBANESS Kongreler Serisi, Tekirdağ, 703-705.

Fagerberg, J. (2003), Innovation: A Guide to Literature, Centre for Technology, Innovation, and Culture. University of Oslo, Norway.

Freeman, C. (1982), The Economics of Industrial Innovation, Francis Pinter, London.

Güler, E. ve Kanber, S. (2011), “İnovasyon aktivitelerinin inovasyon performansı üzerine etkileri: imalat sanayii uygulaması", Cukurova Üniversitesi Sosyal Bilimler Dergisi, 61-76.

Günday, G., Gündüz, U., Kılıç, K. ve Alpkan, L. (2011), "Effects of innovation types on firm performance", Int. Journal of Production Economics, 662-676.

Han, J. ve Kamber, M. (2006), Data Mining: Concepts and Techniques, 2nd ed., Morgan Kaufmann Publishers, San Francisco, USA.

Harmancl, M. ve Önen, M. O. (1999), Dünyada ve Türkiye'de Teknopark ve Teknokent Uygulamaları, Türkiye Kalkınma Bankası A.Ş., Ankara.

JSIC. (2009), Facilitating Open Innovation: Landscape and Feasibility Study, JISC Business and Community Engagement Programme.

Kankanhalli, A. ve Jonathan, Y. (2013), "Exploring innovation through open networks: A review and initial research questions", IIMB Management Review, 69-82.

Narasimahalu, A. (2013), "CUGAR: A model for open innovation in Science", Research Collection School of Information Systems, 1-11.

OECD. (2002), Frascati Kılavuzu, OECD.

OECD. (2005), OSLO Kılavuzu, OECD ve Eurostat ortak yayını.

Oxford Review. https://www.oxfordreview.com/oxford-review-encyclopaediaterms/encyclopaedia-open-innovationdefinition-explanation/, (20.06.2019).

Pado, G. (2016), “Açık İnovasyonun Rekabet Stratejisi Üzerine Etkisi”, Uluslararası Bilimsel Araştırmalar Dergisi, 131-140.

Satı, Z. (2013), İnovasyonu Yönetmede Kesitler: Bilgi Yönetimi/ArGe/Marka, Nobel Yayınları, Ankara.

Schumpeter, J. (1934), The Theory of Economic Development: An Inquiry into Profits, Capital, Credit, Interest and the Business Cycle, Harvard University Press, MA, USA.

Silahtaroğlu, G. (2016), Veri Madenciliği Kavram ve Algoritmaları, Papatya Bilim, İstanbul. 
T.C. Sanayi ve Teknoloji Bakanlığı. https://teknopark.sanayi.gov.tr/Content/Deta $\mathrm{y},(15.05 .2019)$.

Tekin, M., Güleş, H., Ögüt, K. ve Öğüt, A. (2003), Değişim Çağında Teknoloji Yönetimi, Nobel Yayınları, Ankara.

Tunca, M. Z. ve Keleș, M. K. (2009), “Türkiye'de Üniversite-Sanayi İşbirliği ve Teknokentlerin Rolü" (ÜSIMP) Üniversite Sanayi İșbirliği Ulusal Kongresi Bildiriler Kitabı, Eskişehir, 311-322.

Tuominen, M., Piippo, P., Ichimura, T. ve Matsumoto, Y. (1999), "An analysis of innovation management systems' characteristics", Int. Journal of Production Economics, 135-143.

Uzkurt, C. (2008), Pazarlamada Değer Yaratma Aracı Olarak Yenilik Yönetimi ve Yenilikçi Örgüt Kültürü, Beta Yayıncllık, İstanbul.

Ünal, T. ve Seçilmiş, N. (2013), "Ar-Ge Göstergeleri Açısından Türkiye ve Gelişmiş
Ülkelerle Kıyaslaması", İșletme ve íktisat Çalışmaları Dergisi, 12-25.

Veri Bilim Okulu. https://www.veribilimiokulu.com/association -rules-analysis-with-weka/, (30.06.2019).

WEKA.

https://www.cs.waikato.ac.nz/ml/weka/, (21.07.2019).

Witten, I. H., Frank, E. ve Hall, M. A. (2011), Data Mining: Practical Machine Learning Tools and Techniques, 3rd ed., The Morgan Kaufmann Series in DMS, USA.

Yaylalı, M., Akan, Y. ve Ișı, C. (2010), "Türkiye'de Ar-Ge Yatırım Harcamaları ve Ekonomik Büyüme Arasındaki Eş-Bütünleşme ve Nedensellik İlişkisi: 1990-2009", Bilgi Ekon. ve Yönetimi Dergisi, 13-26.

Zerenler, M., Türkey, N. ve Şahin, E. (2007), "Küresel Teknoloji, Araștırma-Geliștirme (ArGe) ve Yenilik İliş̧kisi", Selçuk Üniversitesi Sosyal Bilimler Dergisi, 653-667. 